DOI: 10.32844/2222-5374-2020-104-2.05

УДК:343.2

Константинов О. О., аспірант кафедри кримінального права Національної академії внутрішніх справ

\title{
ОСОБЛИВОСТІ ОБ’ЄКТИВНОЇ СТОРОНИ ДІЯННЯ ПЕРЕДБАЧЕНОГО СТ. 211 КК УКРАЇНИ ВИДАЧА НОРМАТИВНО-ПРАВОВИХ АКТІВ, ЩО ЗМЕНШУЮТЬ НАДХОДЖЕННЯ БЮДЖЕТУ АБО ЗБІЛЬШУЮТЬ ВИТРАТИ БЮДЖЕТУ ВСУПЕРЕЧ ЗАКОНУ
}

У статті здійснено аналіз об'єктивної сторони складу кримінального правопорушення, передбаченого ст. 211 Кримінального кодексу України, «Видання нормативно-правових актів, що зменшують надходження бюджету або збільшують витрати бюджету всупереч закону». Автором визначено, що закінченим дане кримінальне правопорушення має вважатись не з моменту видання зазначеного в диспозищії ч. 1 ст. 211 Кримінального кодексу України нормативно-правового акта, а в залежності від настання наслідків, які на теперішній час хоча і згадуються у статті, однак лише у зв'язку з предметом даного діяння. З'ясовано, що під виданням нормативно-правових актів слід розуміти: підписання службовою особою, наділеною відповідними повноваженнями, актів, які містять приписи, обов'язкові для виконання необмеженим колом об'єктів управління (фізичних та юридичних осіб); затвердження службовою особою своїми наказами актів (постанов, правил, порядку, інструкцій, роз'яснень тощо), прийнятих (схвалених, рекомендованих) колегіальними дорадчими органами (колегіями міністерств, центральних відомств), рішення яких впроваджуються керівниками відповідних органів виконавчої влади, оскільки саме вони несуть персональну відповідальність за виконання завдань іздійснення функцій, покладених на ці органи. Видання нормативноправових актів, що зменшують надходження бюджету або збільшують витрати бюджету, визнається злочином, якщо предметом таких дій були бюджетні кошти у великих розмірах, а саме сума, що в тисячу і більше разів перевищує неоподатковуваний мінімум доходів громадян. Наголошено, що коло суб'єктів бюджетних правопорушень є специфічним. Це викликано особливістю самих бюджетних правовідносин. Суб'єкт бюджетного права $і$ бюджетного правопорушення не співпадають. Суб'єктами бюджетних правопорушень можуть бути як фізичні особи (керівники чи інші відповідальні посадові особи, залежно від характеру вчинених ними діянь), так і колективні утворення. Слід більш чіткіше як у Бюджетному кодексі України так і в Кримінальному законодавстві визначити суб'єктів бюджетних правопорушень, не посилатись на загальну фразу “учасники бюджетного процесу". 
Ключові слова: кримінальне правопорушення, об'єктивна сторона, нормативно-правовий акт, бюджет, надходження, витрати.

Актуальність теми. Загальновідомо, що найбільша кількість правопорушень щодо бюджетних коштів вчинюється саме під час виконання бюджету. Перш за все, тому що вона $є$ найдовшою - триває рік: 31 січня по 31 грудня; по друге - на ній здійснюється фінансування запланованих витрат та накопичення надходжень. Враховуючи ці обставини, законодавець приділив особливу увагу саме цим бюджетним правопорушенням у Бюджетному кодексі України.

Хоч на цій стадії реалізують надані права та виконують обов'язки велике коло суб'єктів, але у Бюджетному кодексі України зосереджується увага лише на деяких бюджетних правопорушеннях, виділяється відповідальність органів місцевого самоврядування, органів Державного казначейства, розпорядників та одержувачів бюджетних коштів.

Виклад основного матеріалу. При виконанні Державного бюджету важливу роль відіграє Міністерство фінансів України, яке має виключне право надання відстрочок по сплаті, податків, зборів(обов'язкових платежів) на умовах податкового кредиту (ст. 50 Бюджетного кодексу). Не своєчасне повернення таких платежів може призвести до негативних наслідків у надходженнях бюджету, тому, Міністерство фінансів повинно нести відповідальність за прийняття необгрунтованого рішення, яке може призвести до дефіциту бюджету. I такі дії даного державного органу слід вважати бюджетним правопорушенням.

Конкретними видами бюджетного правопорушення - $є$ визначені ст. 116 БК України правопорушення, а саме: включення недостовірних даних до бюджетних запитів; порушення встановлених термінів подання бюджетних запитів або їх неподання. визначення недостовірних обсягів бюджетних коштів при плануванні бюджетних показників; планування надходжень або витрат державного бюджету (місцевого бюджету), не віднесених до таких цим Кодексом чи законом про Державний бюджет України; включення до складу спеціального фонду бюджету надходжень 3 джерел, не віднесених до таких цим Кодексом чи законом про Державний бюджет України; зарахування доходів бюджету до іншого, ніж визначено цим Кодексом чи законом про Державний бюджет України, бюджету, в тому числі внаслідок здійснення поділу податків і зборів та інших доходів між бюджетами з порушенням визначених розмірів; прийняття рішень, що призвели до перевищення граничних обсягів державного (місцевого) боргу чи граничних обсягів надання державних (місцевих) гарантій; нецільове використання бюджетних коштів; видання нормативно-правових актів, що зменшують надходження бюджету або збільшують витрати бюджету всупереч закону.

Конкретизується порядок перерахування певних бюджетних коштів різними підзаконними актами, а саме Про затвердження Порядку перерахування до державного бюджету коштів, одержаних від приватизації об>єктів державної власності. Із змінами, внесеними згідно з Наказом Державного казначейства № 212/2057 від 19.11.2003, Кабінет міністрів України Постанова від 15 грудня 2010 р. № 1132, Про 
затвердження Порядку перерахування міжбюджетних трансфертів, тощо.

Суб'єктом бюджетного правопорушення щодо порушення порядку перерахування бюджетних коштів може бути установа банку. Тут вона виступає, як виконавець банківських операцій по перерахуванню коштів клієнтів до бюджетів (у т.ч. щодо сплати податків, зборів та інших обов>язкових платежів), незарахуванню платежів або не в повному обсязі, несвоєчасному зарахуванню платежів.

Суб'єктами даного виду правопорушень можуть бути і підприємства, установи організації, які наповнюють бюджет. При цьому на керівників та інших посадових осіб підприємств, установ, організацій, винних у неподанні або несвоєчасному поданні платіжних доручень на перерахування належних до сплати податків, зборів (обов>язкових платежів), можуть бути застосовані відповідні заходи впливу.

Можна погодитися 3 авторами Коментарю Бюджетного кодексу України [1], які зазначають, що недотримання порядку перерахування бюджетних коштів - це $є$ по суті недотримання порядку проведення операцій з бюджетними коштами, як це встановлено чинним бюджетним законодавством.

Щодо об'єктивної сторони розглядуваного нами кримінального правопорушення то вона характеризується лише активними діями, безпосередньо зазначеними у диспозиції кримінально-правової норми.

Під виданням нормативно-правових актів слід розуміти: підписання службовою особою, наділеною відповідними повноваженнями, актів, які містять приписи, обов'язкові для виконання необмеженим колом об'єктів управління (фізичнихта юридичних осіб); затвердження службовою особою своїми наказами актів (постанов, правил, порядку, інструкцій, роз'яснень тощо), прийнятих (схвалених, рекомендованих) колегіальними дорадчими органами (колегіями міністерств, центральних відомств), рішення яких впроваджуються керівниками відповідних органів виконавчої влади, оскільки саме вони несуть персональну відповідальність за виконання завдань і здійснення функцій, покладених на ці органи.

Видання нормативно-правових актів, що зменшують надходження бюджету або збільшують витрати бюджету, визнається злочином, якщо предметом таких дій були бюджетні кошти у великих розмірах, а саме сума, що в тисячу і більше разів перевищує неоподатковуваний мінімум доходів громадян.

На теперішній час правопорушення вважається закінченим з моменту видання зазначеного в диспозиції ч. 1 ст. 211 КК нормативно-правового акта, незалежно від наслідків, які перебувають за межами складу злочину (формальний склад злочину).

Якщо видання нормативно-правових актів, що зменшують надходження бюджету або збільшують витрати бюджету всупереч закону, поєднується з використанням бюджетних коштів усупереч їх цільовому призначенню або в обсягах, що перевищують затверджені межі видатків вчинене належить кваліфікувати за сукупністю злочинів, передбачених ст. 210 та 211 КК України. 
Заподіяння шкоди охоронюваним законом правам, свободам та інтересам окремих громадян або інтересам юридичних осіб, або державним чи громадським інтересам унаслідок виконання незаконно виданих нормативно-правових активів, що зменшують надходження бюджету або збільшують витрати бюджету всупереч закону, має одержувати самостійну кримінально-правову оцінку і кваліфікуватися за ст. 364 КК України [1].

Однак, ми вважаємо предметом даного кримінального правопорушення лише правові акти, а моментом закінчення кримінального правопорушення визнавати не саме їх видання, а настання шкоди у вигляді - «зменшення надходження бюджету або збільшення витрат бюджету всупереч закону у великих розмірах бюджетних коштів». Таким чином уникнувши моменту невизначеності законодавцем повноти опису предмету даного правопорушення, а також моменту його закінчення.

Аналізуючи та порівнюючи нормативно-правові акти, що регулюють бюджетні правовідносини та кримінально-карані діяння у даній сфері можна зробити деякі висновки:

Визначення поняття “бюджетне правопорушення”, що дається у Бюджетному кодексі України є неточним, оскільки законодавець, формуючи це поняття не приділив належної уваги назвам та змісту стадій бюджетного процесу. Аналізуючи стадії бюджетного процесу можна визначити бюджетне правопорушення як винне протиправне діяння фізичної та юридичної особи, що виражається в порушенні норм бюджетного права, за яке передбачена цивільна, дисциплінарна, адміністративна, кримінальна та фінансово-правова відповідальність. Дане визначення доцільно закріпити у Бюджетному кодексі України.

Поняття “бюджетне правопорушення" та “порушення бюджетного законодавства” не є тотожними. Під останнім слід розуміти недотримання учасником бюджетного процесу встановленого Бюджетним кодексом України та іншими нормативно-правовими актами порядку складання проектів бюджетів, розгляду та прийняття Закону про Державний бюджет України, рішень про місцеві бюджети, виконання бюджету, внесення змін до Закону про Державний бюджет, рішення про місцеві бюджети, підготовки та розгляду звіту про виконання бюджету і прийняття рішень щодо нього.

Коло суб'єктів бюджетних правопорушень $є$ специфічним. Це викликано особливістю самих бюджетних правовідносин. Суб'єкт бюджетного права i бюджетного правопорушення не співпадають. Суб'єктами бюджетних правопорушень можуть бути як фізичні особи (керівники чи інші відповідальні посадові особи, залежно від характеру вчинених ними діянь), так і колективні утворення. Слід більш чіткіше як у Бюджетному кодексі України так і в Кримінальному законодавстві визначити суб’єктів бюджетних правопорушень, не посилатись на загальну фразу “учасники бюджетного процесу”.

Порушенням бюджетного законодавства визнається порушення учасником бюджетного процесу встановлених цим Кодексом чи іншим бюджетним законодавством норм щодо складання, розгляду, затвердження, внесення змін, виконання бюджету та звітування про його виконання, а саме: 
1) включення недостовірних даних до бюджетних запитів;

2) порушення встановлених термінів подання бюджетних запитів або їх неподання;

3) визначення недостовірних обсягів бюджетних коштів при плануванні бюджетних показників;

4) планування надходжень або витрат державного бюджету (місцевого бюджету), не віднесених до таких цим Кодексом чи законом про Державний бюджет України;

5) порушення встановленого порядку або термінів подання проекту закону про Державний бюджет України (проекту рішення про місцевий бюджет) на розгляд Верховної Ради України (Верховної Ради Автономної Республіки Крим, місцевої ради);

6) порушення встановленого порядку або термінів розгляду проекту та прийняття закону про Державний бюджет України (рішення про місцевий бюджет);

7) прийняття рішення про місцевий бюджет з порушенням вимог БК України чи закону про Державний бюджет України (в тому числі щодо складання бюджету в частині міжбюджетних трансфертів);

8) порушення вимог БК України щодо затвердження державного бюджету (місцевого бюджету) з дефіцитом або профіцитом;

9) включення до складу спеціального фонду бюджету надходжень 3 джерел, не віднесених до таких цим Кодексом чи законом про Державний бюджет України;

10) зарахування надходжень бюджету на будь-які рахунки, крім єдиного казначейського рахунка (з урахуванням особливостей, визначених частиною дев'ятою ст. 13 БК України), а також акумулювання їх на рахунках органів, що контролюють справляння надходжень бюджету;

11) зарахування доходів бюджету до іншого, ніж визначено цим Кодексом чи законом про Державний бюджет України, бюджету, в тому числі внаслідок здійснення поділу податків і зборів та інших доходів між бюджетами з порушенням визначених розмірів;

12) здійснення державних (місцевих) запозичень, надання державних (місцевих) гарантій з порушенням вимог БК України;

13) прийняття рішень, що призвели до перевищення граничних обсягів державного (місцевого) боргу чи граничних обсягів надання державних (місцевих) гарантій;

14) розміщення тимчасово вільних коштів бюджету з порушенням вимог БК України;

15) створення позабюджетних фондів, порушення вимог БК України щодо відкриття позабюджетних рахунків для розміщення бюджетних коштів;

16) порушення порядку або термінів подання, розгляду і затвердження кошторисів та інших документів, що застосовуються в процесі виконання бюджету, затвердження у кошторисах показників, не підтверджених розрахунками та економічними обгрунтуваннями;

17) порушення порядку або термінів подання і затвердження паспортів бюджетних програм; 
18) порушення встановлених термінів доведення документів про обсяги бюджетних асигнувань до розпорядників бюджетних коштів нижчого рівня або одержувачів бюджетних коштів;

19) порушення порядку та термінів відкриття (закриття) рахунків в органах Казначейства України;

20) взяття зобов'язань без відповідних бюджетних асигнувань або з перевищенням повноважень, встановлених цим Кодексом чи законом про Державний бюджет України;

21) порушення порядку реєстрації та обліку бюджетних зобов’язань, включаючи необгрунтовану відмову в реєстрації або несвоєчасну реєстрацію бюджетних зобов'язань;

22) порушення вимог БК України при здійсненні попередньої оплати за товари, роботи та послуги за рахунок бюджетних коштів, а також порушення порядку і термінів здійснення такої оплати;

23) здійснення платежів за рахунок бюджетних коштів без реєстрації бюджетних зобов'язань, за відсутності підтвердних документів чи при включенні до платіжних документів недостовірної інформації, а також безпідставна відмова у проведенні платежу органами Казначейства України;

24) нецільове використання бюджетних коштів;

25) порушення вимог БК України при здійсненні витрат державного бюджету (місцевого бюджету) у разі несвоєчасного набрання чинності законом про Державний бюджет України (несвоєчасного прийняття рішення про місцевий бюджет);

26) надання кредитів з бюджету чи повернення кредитів до бюджету з порушенням вимог БК України та/або встановлених умов кредитування бюджету;

27) здійснення бюджетними установами запозичень у будь-якій формі або надання бюджетними установами юридичним чи фізичним особам кредитів з бюджету всупереч БК України;

28) здійснення видатків, кредитування місцевого бюджету, які відповідно до БК України мають проводитися з іншого бюджету;

29) здійснення видатків бюджету чи надання кредитів з бюджету без встановлених бюджетних призначень або з їх перевищенням всупереч цьому Кодексу чи закону про Державний бюджет України;

30) порушення вимог БК України щодо виділення коштів з резервного фонду бюджету;

31) порушення встановлених вимог щодо застосування бюджетної класифікації;

32) включення недостовірних даних до звітів про виконання державного бюджету (місцевого бюджету), річного звіту про виконання закону про Державний бюджет України (рішення про місцевий бюджет), а також порушення порядку та термінів подання таких звітів;

33) порушення встановлених вимог щодо ведення бухгалтерського обліку та складання звітності про виконання бюджетів;

34) порушення встановлених порядку або термінів подання фінансової і бюджетної звітності бюджетних установ, а також подання такої звітності у неповному обсязі; 
35) невідповідність даних, наведених у фінансовій і бюджетній звітності бюджетних установ, даним бухгалтерського обліку;

36) включення недостовірних даних до звітів про виконання паспортів бюджетних програм, а також порушення порядку та термінів подання таких звітів;

37) видання нормативно-правових актів, що зменшують надходження бюджету або збільшують витрати бюджету всупереч закону;

38) здійснення видатків на утримання бюджетної установи одночасно з різних бюджетів всупереч цьому Кодексу чи закону про Державний бюджет України;

39) порушення вимог статті 28 БК України щодо оприлюднення та доступності інформації про бюджет;

40) інші випадки порушення бюджетного законодавства учасником бюджетного процесу [3].

Зазначимо, що об'єктивна сторона розглядуваного нами кримінального правопорушення повністю співпадає 3 п. 37, ст. 116 БК України, що говорить про її економічну складову та має важливе значення при відмежуванні одного правопорушення від іншого.

\section{СПИСОК ВИКОРИСТАНИХ ДЖЕРЕЛ}

1. Коментар до Бюджетного кодексу України - Режим доступу: https:// legalexpert.in.ua/komkodeks/bku.html

2. Науково-практичний коментар Кримінального кодексу України / Д.С. Азаров, В.К. Грищук, А.В. Савченко [та ін.] ; За заг. ред. О.М. Джужі, А.В. Савченка, В.В. Чернєя; НАВС. - К.: Юрінком Інтер, 2018. 1064 с.

3.Бюджетний кодекс України - Режим доступу: https://legalexpert. in.ua/komkodeks/bku/92-bku/4629-116.html

\section{O. Konstantynov}

\section{PECULIARITIES OF THE OBJECTIVE SIDE OF THE ACTION PROVIDED ST. 211 OF THE CRIMINAL CODE OF UKRAINE ISSUANCE OF REGULATORY LEGAL ACTS THAT REDUCE BUDGET REVENUE OR INCREASE EXPENDITURE OF THE BUDGET CONTRARY TO THE LAW}

The article analyzes the objective side of the criminal offense provided for in Art. 211 of the Criminal Code of Ukraine, "Edition of normative legal acts that reduce budget receipt or increase budget expenditures contrary to the law." The author determined that completed this criminal offense should be considered not from the date of publication of the specified in the disposition of Part 1 of Art. 211 of the Criminal Code of Ukraine of the normative legal act, and depending on the onset of the consequences, which at present, although referred to in the article, but only in connection with the subject of this act. It was found that the issuance of regulations should be understood as: signing by an official with the appropriate powers, acts that contain instructions that are mandatory for an unlimited number of objects of management (individuals and legal entities); approval by an official of his orders of acts (resolutions, rules, procedures, instructions, explanations, etc.) adopted (approved, recommended) by collegial advisory bodies (boards of minis- 
tries, central departments), the decisions of which are implemented by the heads of relevant executive bodies, because they are personally responsible for the performance of tasks and functions assigned to these bodies. The issuance of regulations that reduce budget revenues or increase budget expenditures is considered a crime if the subject of such actions were budget funds in large amounts, namely the amount that is a thousand times or more than the tax-free minimum income. It is emphasized that the range of subjects of budget violations is specific. This is due to the peculiarity of the budgetary legal relations. The subject of budget law and budget offense do not coincide. The subjects of budget violations can be both individuals (managers or other responsible officials, depending on the nature of their actions) and collective entities. It is necessary to define more clearly both in the Budget code of Ukraine and in the Criminal legislation subjects of budgetary offenses, not to refer to the general phrase "participants of budgetary process".

Keywords: criminal offense, objective side, normative legal act, budget, receipt, expenses. 